\title{
Protein sparing effect of dietary lipids in common dentex (Dentex dentex): a comparative study with sea bream (Sparus aurata) and sea bass (Dicentrarchus labrax)
}

\author{
Rubén Company ${ }^{(a)}$, Josep A. Calduch-Giner ${ }^{(a)}$, Jaume Pérez-Sánchez ${ }^{(a)}$, \\ Sadasivam J. Kaushik ${ }^{(b *)}$ \\ (a) Instituto de Acuicultura de Torre de la Sal (CSIC), 12595 Ribera de Cabanes, Castellón, Spain. \\ (b) Laboratoire de nutrition des poissons, Unité mixte Inra-Ifremer, BP 3, 64310 Saint-Pée-sur-Nivuelle, France.
}

Received September 18; accepted December 18, 1998.

\begin{abstract}
The common dentex (Dentex dentex) is a sparid fish which is considered a suitable candidate for Mediterranean aquaculture. A seven-weeks feeding trial was conducted over the summer period with common dentex, sea bream (Sparus aurata) and sea bass (Dicentrarchus labrax). All three species were fed to visual satiety with two practical diets with varying crude protein and crude fat levels ( $55 \%$ protein, $9 \%$ lipids; $46 \%$ protein, $17 \%$ lipids). The initial body weights were $8.2,11.6$ and $17.3 \mathrm{~g}$ for common dentex, sea bass and sea bream, respectively. In all cases, specific growth rates were not significantly affected by dietary treatment, but they varied among species (sea bass $1.7-1.8 \%$; sea bream 2.1-2.3\%; common dentex 3.1-3.2\%). When comparisons between fish species were made, we observed that the increase in growth rates was linked to a decrease of the whole body fat content, as a consequence of a greater utilisation of dietary lipids as energy substrates. Furthermore, in common dentex, the $17 \%$ lipid diet was able to improve protein retention, but this diet effect was less significant in sea bream and sea bass. In contrast to sea bream, the $17 \%$ lipid diet did not up-regulate plasma GH levels in common dentex, which provides additional evidence for a more efficient utilisation of dietary lipids. (C) Ifremer/Elsevier, Paris
\end{abstract}

Growth performance / protein retention / energy availability / growth hormone / Dentex dentex / Dicentrarchus labrax / Sparus aurata

Résumé - Rétention de protéines suite à un régime riche en lipides chez le dentex (Dentex dentex) : étude comparée avec la daurade (Sparus aurata) et le bar (Dicentrarchus labrax). Le dentex est un sparidé reconnu comme ayant un potentiel aquacole en Méditerranée. Une étude comparative de croissance entre le dentex, la daurade et le bar a été réalisée. Les trois espèces (poids moyen initial : 8,$2 ; 11,6$ et 17,3 g respectivement pour le dentex, le bar et la daurade) ont été nourries à satiété avec deux régimes expérimentaux ( $55 \%$ de protéines brutes avec $9 \%$ de lipides ou $46 \%$ de protéines brutes avec $17 \%$ de lipides). Chez chacune des espèces, le taux de croissance spécifique (TCS) n'a pas varié en fonction du régime alimentaire. En revanche, une différence significative interspécifique a été observée (bar $1,7-1,8 \%$; daurade $2,1-2,3 \%$; dentex $3,1-3,2 \%$ ) avec également une différence significative dans le dépôt lipidique corporel, reflétant des différences dans l'utilisation des apports énergétiques d'origine lipidique. L'effet de rétention de protéines par des lipides a été plus important chez le dentex que chez les deux autres espèces. Par ailleurs, contrairement à ce qui est observé chez la daurade, le régime riche en lipides n'induit pas une régulation de la sécrétion de l'hormone de croissance chez le dentex, indiquant aussi une meilleure utilisation des lipides alimentaires. $\mathcal{C}$ Ifremer/Elsevier, Paris

Croissance / rétention protéinique / énergie digestible / hormone de croissance / Dentex dentex / Dicentrarchus labrax / Sparus aurata

\section{INTRODUCTION}

The common dentex (Dentex dentex) is naturally present in the Mediterranean area, and spawns between

* Corresponding author, e-mail: kaushik@st-pee.inra.fr
March and July at temperatures of $15^{\circ} \mathrm{C}$ or higher [25]. This sparid fish inhabits rocky bottoms $200 \mathrm{~m}$ deep and preys on fish, mollusks and worms. In nature, the maximum recorded length is $100 \mathrm{~cm}$, but the mean 
size at capture ranges between 35 and $40 \mathrm{~cm}$ [35]. Nowadays, common dentex is produced on a pilot scale in Greece, Italy and Spain, but this species is known to be extremely sensitive to handling and opportunistic pathogens [10, 32]. Despite this, fast growth has been reported during larval $[1,41]$ and fry stages [13] when natural food and moist pellets are used. According to Riera et al. [31], fingerling fish reared in sea cages with natural food can reach $830 \mathrm{~g}$ in 16-17 months, with growth rates twice that of sea bass (Dicentrarchus labrax) and sea bream (Sparus aurata). Under experimental conditions however, with practical diets, feed efficiency has been found to be relatively poor, and within the values reported for sea bass and sea bream $[8,38]$. This apparent contradictory finding remains unclear, and could reflect the lack of standard protocols for a correct assessment and comparison of fish growth. Thus, to further address the suitability of common dentex as a candidate for Mediterranean aquaculture, a comparative feeding trial (common dentex vs. sea bass and sea bream) was carried out in the present work.

\section{MATERIALS AND METHODS}

\subsection{Animals}

Experimental fish were obtained as fry from two Spanish fish farms (Cupimar, Cadiz; Gesa, Mallorca). Rearing was conducted in $150-\mathrm{L}$ aquaria with running seawater free of organic matter. Photoperiod and water temperature followed the natural cycle.

\subsection{Diets}

Two experimental diets which differed in crude protein (CP) and crude fat (CF) levels were formulated (55CP:9CF and 46CP:17CF, table I). The gross energy (GE) content was 20.8 and $22.4 \mathrm{~kJ} \cdot \mathrm{g}^{-1}$ dry matter. Dry pellets were manufactured using a laboratory pellet mill without steam conditioning, and stored at $4{ }^{\circ} \mathrm{C}$ until use.

\subsection{Feeding trial}

Fingerling fish averaging 8.2 (common dentex), 11.6 (sea bass) and $17.3 \mathrm{~g}$ (sea bream) were randomly allocated to duplicate groups of 60 fish for each dietary treatment. Fish were fed to satiety by hand three times a day. Water temperature ranged from 23 to $26^{\circ} \mathrm{C}$ over the course of the trial ( 7 weeks, July-September). At the end of the experiment and following an overnight fasting, 20 fish per dietary treatment were withdrawn and anaesthetised with MS-222 (Sigma, St Louis, $\mathrm{MO}$ ). Blood was obtained from caudal vessels, centrifuged $30 \mathrm{~min}$, at $2500 \times \mathrm{g}$ and the resulting plasma samples were stored at $30^{\circ} \mathrm{C}$ until analysed. Additionally, 10 fish at the beginning and 15 fish from each tank at the end of the experiment were withdrawn and
Table I. Ingredient content and proximate composition of experimental diets. CP: Crude protein; CF: crude fat.

\begin{tabular}{lcc}
\hline & \multicolumn{2}{c}{ Diet } \\
\cline { 2 - 3 } & 55CP:9CF & 46CP:17CF \\
\hline g.100 g wet matter & -1 \\
Fish soluble protein concentrate & 5 & 5 \\
$\quad$ (CPSP) & & \\
Fish meal (Norway) & 55 & 40 \\
Corn gluten meal & 10 & 10 \\
Fish oil & 2 & 11 \\
Extruded pcas (Aquatcx, France) & 24 & 30 \\
Mineral premix 1 & 2 & 2 \\
Vitamin premix ${ }^{2}$ & 2 & 2 \\
Proximate composition & & \\
Dry matter (DM, \%) & 84.3 & 88.0 \\
Crude protein (\% DM) & 55.3 & 46.4 \\
Crude fat (\% DM) & 9.3 & 17.4 \\
Total phosphorus (\% DM) & 1.7 & 1.4 \\
Ash (\% DM) & 11.8 & 9.4 \\
Gross energy (kJ.g ${ }^{-1}$ DM) & 20.9 & 22.4 \\
Protein:energy ratio (mg $\cdot \mathrm{kJ}^{-1}$ ) & 26.5 & 20.7 \\
\hline
\end{tabular}

'Supplied the following (per $\mathrm{kg}^{-1}$ diet): calcium carbonate $(40 \% \mathrm{Ca})$, $2.15 \mathrm{~g}$; magnesium hydroxide $(60 \% \mathrm{Mg}), 1.24 \mathrm{~g}$; potassium chloride, $0.9 \mathrm{~g}$; ferric citrate, $0.2 \mathrm{~g}$; potassium iodine, $4 \mathrm{mg}$; sodium chloride, $0.4 \mathrm{~g}$; calcium hydrogen phosphate, $50 \mathrm{~g}$; copper sulfate, $0.3 \mathrm{mg}$; zinc sulfate, $40 \mathrm{mg}$; cobalt sulfate, $2 \mathrm{mg}$; manganese sulfate, $30 \mathrm{mg}$; sodium selenite, $0.3 \mathrm{mg}$.

${ }^{2}$ Supplied the following (mg $\mathrm{kg}^{-1}$ diet): retinyl acetate, 2.58 ; DL-cholecalciferol, 0.037; DL-cholecalciferol tocopheryl acetate, 30; menadione sodium bisulfite, 2.5 ; thiamine, 7.5 ; riboflavin, 15 ; pyridoxine, 7.5; nicotinic acid, 87.5 ; folic acid, 2.5 ; calcium pantothenate, 2.5 ; vitamin B I2, 0.025; ascorbic acid, 250; inositol, 500; biotin, 1.2; choline chloride, 500 .

killed to perform body composition analysis. Whole body samples were ground before analyses. A small aliquot was dried in an oven at $110^{\circ} \mathrm{C}$ for $24 \mathrm{~h}$ in order to estimate water content. The remaining samples were freeze-dried, and chemical analyses were performed according to AOAC methods: crude protein by Kjeldahl $(\mathrm{N} \times 6.25)$ after acid-digestion, fat according to the method of Folch et al. [14], ash after $2 \mathrm{~h}$ of combustion at $600{ }^{\circ} \mathrm{C}$, and gross energy using an adiabatic bomb calorimeter.

\subsection{Biochemical analyses}

Plasma glucose levels were determined spectrophotometrically using a commercial kit (Sigma). Plasma growth hormone $(\mathrm{GH})$ levels were determined using a sensitive and specific radioimmunoassay (RIA) for recombinant sea bream GH (rsbGH) [20]. The sensilivity and midrange $\left(\mathrm{ED}_{50}\right)$ of the assay were 15 and $210 \mathrm{pg}$, respectively. To validate this $\mathrm{GH}$ assay for common dentex, the parallelism of standard curve with serial dilutions of plasma and pituitary homogenates was established (figure I). The recovery of rsbGH 


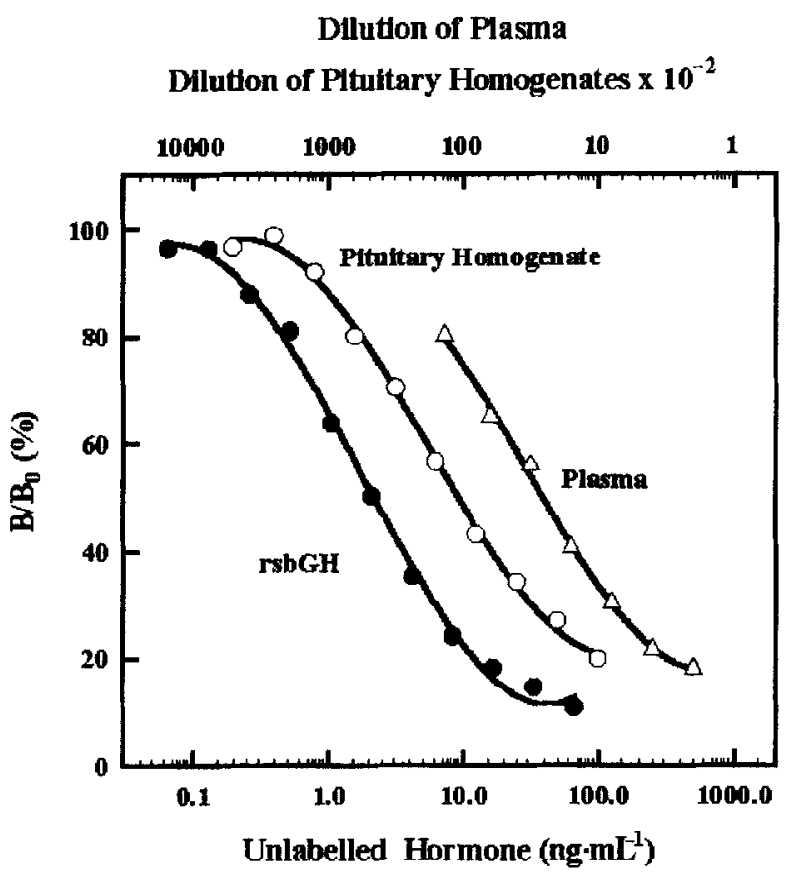

Figure 1. Competitive displacement of ${ }^{125} \mathrm{I}$-rsbGH by unlabelled rsb$\mathrm{GH}$ and serial dilutions of plasma and pituitary homogenates of common dentex. Initial dilution of pituitary homogenate: $1 \mathrm{~mL}$ RIA buffer $100 \mathrm{~g}^{-1}$ body weight. Each value is the mean of $3-4$ replicates.

added to plasma samples of common dentex was $97.3 \pm 1.5(n=4)$.

\subsection{Statistics}

Data were analysed by one-way analysis of variance, followed by Duncan's multiple range test. Curve parallelism was tested by covariance analysis. $P<0.05$ was considered statistically significant.

\section{RESULTS}

\subsection{Growth performance}

Data on growth performance of the three marine teleosts are summarised in table II. Under our experimental conditions of unrestricted feeding, the total voluntary feed intake was not significantly affected $(P<0.05)$ by diet composition in any of the fish species examined. However, expressed as a percentage of mean body weight, the daily feed intake of sea bass and sea brean was slightly higher in fish fed the $17 \%$ lipid diet. Differences in specific growth rates (SGR) were found among fish species (common dentex $>$ sea bream > sea bass) but, for each fish species, it was not significantly affected $(P<0.05)$ by dietary treatment. The slope of plot regression of weight vs. culture time (figure 2) was also higher in common dentex, indicating that differences in SGR between species were not only due to differences in initial body weight.

In common dentex, feed gain ratio (FGR) was near to 1 with both experimental diets. In sea bass and sea bream, FGR was 1.25 and 1.5 with the 9 and $17 \%$ lipid diet, respectively. Protein efficiency ratios (PER) were also found to differ between species. In common dentex, PER in fish fed the $9 \%$ lipid diet was 1.7, and increased up to 1.9 with the $17 \%$ lipid diet. In both sea bass and sea bream, PER remained around 1.4 with both dietary treatments.

\subsection{Body composition}

Data on whole body composition are reported in table III. In all cases, fish fed the $17 \%$ lipid diet exhibited a higher whole body lipid content (\% dry matter) in combination with a decreased protein content. Common dentex showed the lowest daily fat gain $\left(\mathrm{g} \cdot \mathrm{kg}^{-1}\right.$ body weight) followed by sea bream and sea bass. An opposite trend was found in terms of daily $\mathrm{N}$ gain

Table II. Growth performance of sea bass, sea bream and common dentex fed the experimental diets for seven weeks. Values are means \pm SEM of duplicate tanks. Values that share a common letter are not significantly different $(P<0.05)$. CP: Crude protein; CF: crude fat.

\begin{tabular}{|c|c|c|c|c|c|c|}
\hline \multirow[t]{2}{*}{ Diet } & \multicolumn{2}{|c|}{ Sea bass } & \multicolumn{2}{|c|}{ Sea bream } & \multicolumn{2}{|c|}{ Common dentex } \\
\hline & $55 \mathrm{CP}: 9 \mathrm{CF}$ & 46CP:17CF & $55 \mathrm{CP}: 9 \mathrm{CF}$ & $46 \mathrm{CP}: 17 \mathrm{CF}$ & $55 \mathrm{CP}: 9 \mathrm{CF}$ & $46 \mathrm{CP}: 17 \mathrm{CF}$ \\
\hline \multicolumn{7}{|l|}{ Feed intake } \\
\hline Dry matter (g) & $20.3 \pm 0.88^{a}$ & $21.9 \pm 0.01^{a}$ & $40.3 \pm 0.70^{b}$ & $43.8 \pm 2.13$ & $30.3 \pm 1.30^{\circ}$ & $30.5 \pm 1.52^{\mathrm{c}}$ \\
\hline Dry matter (\% BW/day) & $2.19 \pm 0.04^{a}$ & $2.44 \pm 0.04$ ab & $2.63 \pm 0.01^{h}$ & $3.07 \pm 0.11^{\mathrm{c}}$ & $2.91 \pm 0.08^{c}$ & $3.09 \pm 0.04^{\mathrm{c}}$ \\
\hline \multicolumn{7}{|l|}{ Growth performance } \\
\hline Initial body weight $\left(\mathrm{BW}_{0}\right)(\mathrm{g})$ & $11.6 \pm 0.07^{b}$ & $11.6 \pm 0.19^{b}$ & $17.5 \pm 0.95^{c}$ & $17.1 \pm 0.17^{c}$ & $8.4 \pm 0.04^{a}$ & $8.0 \pm 0.12^{a}$ \\
\hline Final body weight $\left(\mathrm{BW}_{f}\right)(\mathrm{g})$ & $27.8 \pm 1.02^{a}$ & $26.5 \pm 0.36$ & $49.9 \pm 1.20^{\circ}$ & $45.5 \pm 0.39^{\mathrm{c}}$ & $36.9 \pm 1.64^{b}$ & $34.7 \pm 1.56^{\mathrm{b}}$ \\
\hline SGR & $1.86 \pm 0.09^{a}$ & $1.76 \pm 0.01$ & $2.31 \pm 0.04^{b}$ & $2.15 \pm 0.02^{a b}$ & $3.23 \pm 0.06^{\mathrm{c}}$ & $3.19 \pm 0.14^{\mathrm{c}}$ \\
\hline $\mathrm{FGR}^{2}$ & $1.25 \pm 0.03^{\mathrm{a}}$ & $1.47 \pm 0.02^{b}$ & $1.24 \pm 0.01^{a}$ & $1.54 \pm 0.04^{b}$ & $1.06 \pm 0.01^{\mathrm{c}}$ & $1.14 \pm 0.03^{c}$ \\
\hline $\mathrm{PER}^{3}$ & $1.44 \pm 0.03^{\mathrm{a}}$ & $1.42 \pm 0.02$ & $1.46 \pm 0.02^{a}$ & $1.40 \pm 0.04^{a}$ & $1.70 \pm 0.02^{1}$ & $1.90 \pm 0.03^{\mathrm{c}}$ \\
\hline Mortality (\%) & - & - & - & - & $4-7$ & $4-6$ \\
\hline
\end{tabular}

\footnotetext{
'SGR: Specific growth rate $=100 \times\left(\ln B W_{f}-\ln B W_{0}\right) /$ days.

${ }^{2}$ FGR: Feed gain ratio $=$ dry feed intake/wet weight gain.

${ }^{3}$ PER: Protein efficiency ratio $=100 \times$ (wet weight gain/crude protein intake).
} 


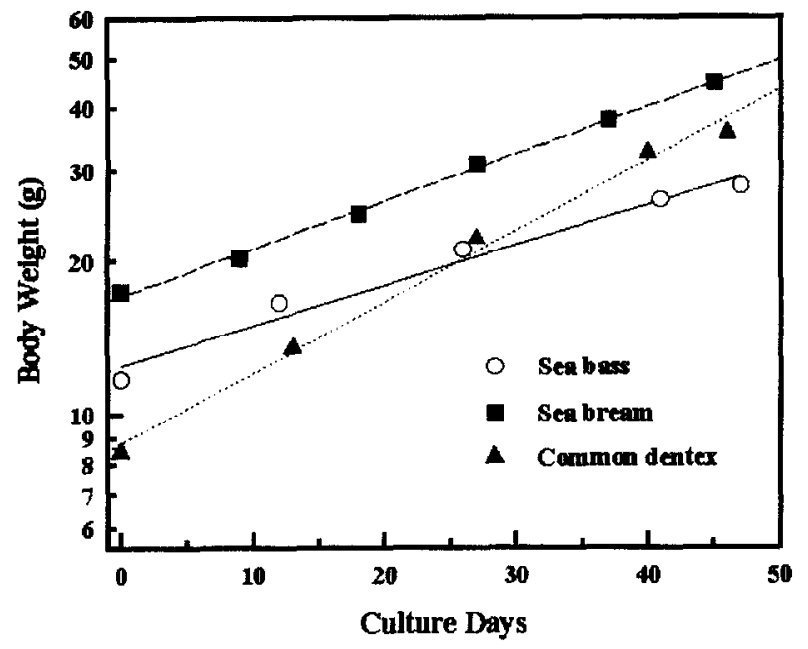

Figure 2. Plot regression of body weight (BW) versus days (d) of culture in common dentex $\left(\log B W=0.942+0.014 \mathrm{~d} ; r^{2}=0.99\right)$, sea bream $\left(\log \mathrm{BW}=1.230+0.0092 \mathrm{~d} ; r^{2}=0.99\right)$ and sea bass $(\operatorname{logBW}=$ $1.097+0.0077 \mathrm{~d} ; r^{2}=0.97$ ). No significant differences were found between dietary treatments, and each value is the mean of the two experimental groups.

( $\mathrm{mg} \cdot \mathrm{kg}^{-1}$ body weight) (common dentex $>$ sea bream $>$ sea bass). For all three species, fat retention was always lower in fish fed the $17 \%$ lipid diet than in those fed the $9 \%$ lipid diet. In common dentex, protein retention increased significantly with the increase of dietary lipids, while a slight but not significant decrease was found in sea bream and sea bass.

\subsection{Plasma glucose and growth hormone}

Significant differences in mean plasma glucose levels were observed between species (figure 3). Following overnight fasting, a significant effect of diet composition on plasma glucose levels was found only in sea bass. However, as a general pattern, plasma glucose levels were lower in fish fed the $17 \%$ lipid diet.

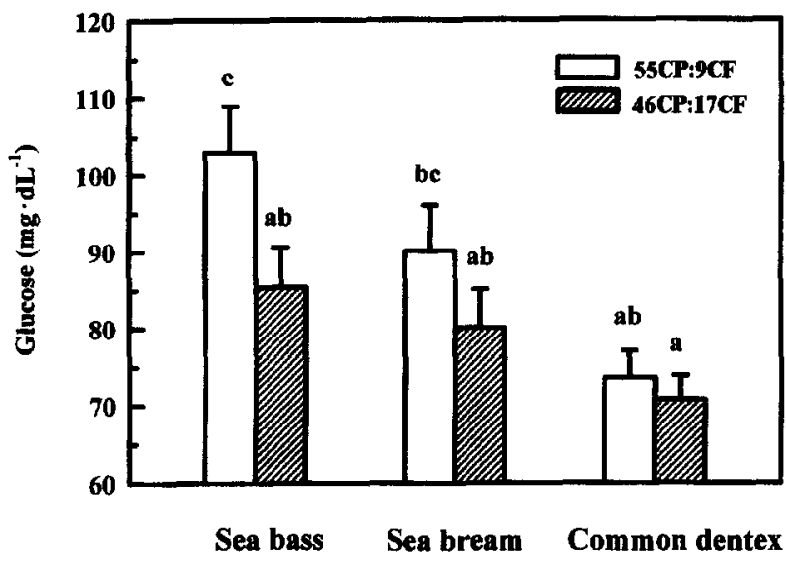

Figure 3. Plasma glucose levels following ovcrnight fasting in sea bass, sea bream and common dentex fed the experimental diets for seven weeks. Each value is the mean \pm SEM of 15-20 fish. Values that share common letters were not significantly different $(P<0.05)$.

Plasma GH levels were not measured in sea bass due to the lack of a validated assay. Comparisons among fish specics werc therefore limited to sea bream and common dentex (figure 4). The mean plasma GH concentration was higher in sea bream than in common dentex. In sea bream, plasma GH levels increased significantly in fish fed the $17 \%$ lipid diet. An opposite, although non-significant effect, was found in common dentex.

\section{DISCUSSION}

Literature data on the growth of Mediterranean marine finfish species appear to be rather highly variable (table IV), probably due to differences in fish strains, water quality and temperature, oxygen availability, biomass density and biological value of dietary protein and non-protein energy substrates. Most of the experimental data are also clearly in contrast with the

Table III. Whole body composition and nutrient utilisation in sea bass, sea bream and common dentex fed the experimental diets for seven weeks. Values are means \pm SFM of duplicate tanks. Values that share a common letter are not significantly different $(P<0.05)$. CP: Crude protein; CF: crude fat.

\begin{tabular}{|c|c|c|c|c|c|c|}
\hline \multirow[t]{2}{*}{ Diet } & \multicolumn{2}{|c|}{ Sea bass } & \multicolumn{2}{|c|}{ Sea bream } & \multicolumn{2}{|c|}{ Common dentex } \\
\hline & $55 \mathrm{CP}: 9 \mathrm{CF}$ & $46 \mathrm{CP}: 17 \mathrm{CF}$ & $55 \mathrm{CP}: 9 \mathrm{CF}$ & $46 \mathrm{CP}: 17 \mathrm{CF}$ & 55CP:9CF & $46 \mathrm{CP}: 17 \mathrm{CF}$ \\
\hline Water $(\%)$ & $66.9 \pm 0.4^{a}$ & $64.8 \pm 0.6^{b}$ & $69.5 \pm 0.4^{\mathrm{c}}$ & $67.9 \pm 0.4^{n}$ & $72.8 \pm 0.2^{\mathrm{d}}$ & $71.9 \pm 0.3^{\mathrm{d}}$ \\
\hline Protein (\% fresh weight) & $16.2 \pm 0.2^{\mathrm{a}}$ & $15.6 \pm 0.5^{\circ}$ & $16.9 \pm 0.1^{a}$ & $16.7 \pm 0.1^{a}$ & $16.67 \pm 0.1^{\mathrm{a}}$ & $16.1 \pm 0.4^{a}$ \\
\hline Fat ( $\%$ fresh weight) & $11.1 \pm 0.3^{d}$ & $13.7 \pm 0.2^{\mathrm{e}}$ & $8.6 \pm 0.4^{c}$ & $11.0 \pm 0.1^{\mathrm{d}}$ & $4.5 \pm 0.5^{a}$ & $6.1 \pm 0.2^{b}$ \\
\hline Ash (\% fresh weight) & $4.0 \pm 0.2^{a}$ & $3.9 \pm 0.2^{a}$ & $4.6 \pm 0.2^{a}$ & $4.2 \pm 0.2^{a}$ & $4.6 \pm 0.2^{a}$ & $4.6 \pm 0.1^{a}$ \\
\hline Gross energy $\left(\mathrm{kJ} \cdot \mathrm{g}^{-1} \mathrm{DM}\right)$ & $24.1 \pm 0.4^{b}$ & $24.6 \pm 0.1^{b}$ & $23.0 \pm 0.3^{b}$ & $24.2 \pm 0.3^{b}$ & $21.0 \pm 0.6^{\mathrm{a}}$ & $21.5 \pm 0.2^{\mathrm{a}}$ \\
\hline $\mathrm{N}$ gain $\left(\mathrm{mg} \cdot \mathrm{kg}^{-1} \mathrm{BW} \cdot \mathrm{day}^{-1}\right)$ & $444.7 \pm 30.7^{\mathrm{a}}$ & $392.3 \pm 23.3^{\mathrm{a}}$ & $580.1 \pm 7.3^{c}$ & $525.4 \pm 2.8^{b}$ & $754.5 \pm 8.7^{d}$ & $733.3 \pm 14.3^{d}$ \\
\hline Fat gain $\left(\mathrm{mg} \cdot \mathrm{kg}^{-1} \mathrm{BW} \cdot \mathrm{day}^{-1}\right)$ & $2.23 \pm 0.17^{b}$ & $2.89 \pm 0.02^{c}$ & $1.93 \pm 0.02^{b}$ & $2.58 \pm 0.01$ & $1.31 \pm 0.16^{a}$ & $1.87 \pm 0.04^{b}$ \\
\hline Protein retention & $22.9 \pm 1.1^{\mathrm{a}}$ & $21.7 \pm 1.7^{a}$ & $25.0 \pm 0.3^{a}$ & $23.1 \pm 0.7^{\text {a }}$ & $29.0 \pm 0.3^{b}$ & $32.6 \pm 0.2^{c}$ \\
\hline Fat retention ${ }^{2}$ & $109.5 \pm 5.9^{d}$ & $68.1 \pm 2.2^{\mathrm{c}}$ & $78.9 \pm 0.7^{\circ}$ & $48.4 \pm 1.7^{b}$ & $48.7 \pm 6.9^{b}$ & $34.6 \pm 1.0^{\circ}$ \\
\hline
\end{tabular}

Initial body composition for sea bass, sea bream and common dentex: water: $69.4,71.6,75.6 \%$; protein: $16.7,17.1,15.45 \%$; fat: $8.8,7.8,3.4 \%$; ash: $4.2,4.0,4.0 \%$.

${ }^{1}$ Protein retention $=100 \times($ fish protein gain/protein intake $)$.

${ }^{2}$ Fat retention $=100 \times($ fish lipid gain/lipid intake $)$. 


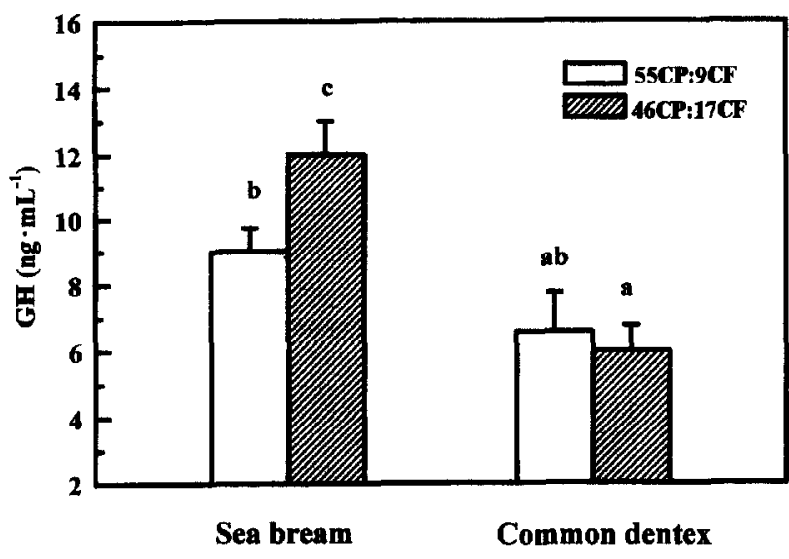

Figure 4. Plasma growth hormone $(\mathrm{GH})$ levels following overnight fasting in sea bream and common dentex fed the experimental diets for seven weeks. Each value is the mean \pm SEM of 15-20 fish. Values that share common letters were not significantly different $(P<0.05)$.

predicted values of Russell et al. [33] for 15-g fish ( $\mathrm{SGR} \leq 1$; FGR $>4)$.

In the present study, SGR $(1.7-1.8 \%)$ and FGR $(1.2-1.5)$ of fingerling sea bass were better or within the range of previous studies (table IV). This observation can also be extended to sea bream, where a SGR of $2.3 \%$ and a FGR of 1.25 was achieved with $17-50-\mathrm{g}$ fish. In the study of Tandler et al. [37], 10-g sea bream reared at $25-26^{\circ} \mathrm{C}$ showed growth rates of only $1 \%$ body weight per day. For fish of a lower body weight range (5-30 g), a better growth (2.5-2.9\%) and FGR (1.4-1.6) was reported by Vergara et al. [42] under a fixed feeding level. However, these values were still far from the best feed conversion in fast growing fish, since a SGR near $3 \%$ with a FGR close to 1 can be achieved with $15-50-\mathrm{g}$ fish, when they are fed with high protein and low lipid diets [21].

Fast growth and efficient feed conversion were observed with common dentex. Thus, when growth rates and protein retention were considered together, the obtained values were better than those previously reported not only for sea bass and sea bream, but also for common dentex (see table IV). With three protein $(45,50$ and $55 \%)$ and two lipid levels (12 and $17 \%)$, Tibaldi et al. [38] reported a protein sparing effect of dietary lipids in 20-46-g common dentex. However, SGR was relatively low $(1.4 \%)$ and protein retention reached a maximum value of $22 \%$. With the same range of body size, Cardenete et al. [8] observed a protein sparing effect when dietary lipid levels increased from 17 to $22 \%$ with $54 \%$ crude protein diets, but growth rates remained low. For $10-40-\mathrm{g}$ fish, the same authors [7] indicated that common dentex can exhibit a SGR of $3 \%$ with a FGR of 1.1-1.3, although the protein sparing effect of an increase in dietary lipids was not clear and PER remained around 1.5. In the present study, under similar experimental conditions, with comparable SGR, PER was found to increase with the decrease of dietary protein:energy ratio.

Taking together all the above data, when comparisons are made between the three species, common dentex had the best growth performance and daily protein accretion ( $\mathrm{N}$ gain). A possible explanation is a more efficient utilisation of dietary lipids as energy substrates, as shown by a lower fat retention and body fat content. Under our experimental conditions of high temperature and unrestricted feeding, dietary lipids appear to spare proteins for growth purposes in dentex. However, in both sea bass and sea bream, present data do not suggest any improvement of protein retention with the increase of dietary lipids. This finding is in apparent contradiction with the recent work of Dias et al. [11], in which sea bass fingerlings were shown to grow efficiently at $18{ }^{\circ} \mathrm{C}$ with a $42 \%$ protein and $18 \%$ lipid diet. They also found that the protein sparing effect was less significant with high protein diets. However, as it was pointed out in a previous work [6],

Table IV. Data base of published papers for sea bass, sea bream and common dentex,

\begin{tabular}{|c|c|c|c|c|c|c|}
\hline Fish species & Weight range (g) & Temp $\left({ }^{\circ} \mathrm{C}\right)$ & $\mathrm{SGR}^{*}(\%)$ & FGR* & PER* & Reference \\
\hline Sea bass & $3-6$ & $19-22$ & $1.6-2$ & $1.6-2.7$ & - & Tsevis et al. [40] \\
\hline$“$ & $3-17$ & $26-28$ & $1.6-2$ & $1.4-2.2$ & $0.9-1.7$ & Pérez et al. [26] \\
\hline “ & $6-11$ & 19 & $0.7-0.8$ & $1.3-1.7$ & $1.2-1.7$ & Dias et al. [11] \\
\hline “ & 15 & 20 & 1 & $>4$ & - & Russell et al. [33] \\
\hline “ & $31-56$ & 20 & 1 & $1.5-1.6$ & 1.3 & Hidalgo and Alliot [16] \\
\hline “ & $75-115$ & 19 & $0.4-0.5$ & $2.0-2.3$ & $0.7-0.9$ & Metailler et al. [24] \\
\hline “ & $75-230$ & $23-27$ & $0.5-0.6$ & $1.6-1.9$ & $1.2-1.3$ & Ballestrazzi et al. [3] \\
\hline “ & $80-329$ & 23 & $0.6-0.7$ & $1.4-1.6$ & $1.2-1.5$ & Ballestrazzi et al. [2] \\
\hline Sea bream & $10-15$ & $24-27$ & $0.5-1.0$ & - & - & Tandler et al. [37] \\
\hline “ & $5-29$ & $21-22$ & $2.5-2.9$ & $1.4-1.6$ & - & Vergara et al. [42] \\
\hline " & $13-35$ & $23-26$ & 1.7 & 1.1 & 1.9 & Calduch-Giner et al. [6] \\
\hline “ & $15-51$ & $21-23$ & $2.6-3$ & $1-1.6$ & $1.3-1.4$ & Martí-Palanca et al. [21] \\
\hline Common dentex & $2-16$ & $24-26$ & $3.8-5.2$ & $0.9-1.1$ & - & Efthimiou et al. [13] \\
\hline “ & $10-40$ & 20 & $3-3.4$ & $1.1-1.3$ & 1.5 & Cardenete et al. [7] \\
\hline$"$ & $21-46$ & 20 & $1.2-1.3$ & $1.8-2.1$ & $1-1.3$ & Tibaldi et al. [38] \\
\hline “ & $31-61$ & 20 & $0.7-0.8$ & $1.4-1.6$ & $1.2-1.4$ & Cardenete et al. [8] \\
\hline
\end{tabular}

See foot notes to table 11 .

Aquat. Living Resour. 12 (1) (1999) 
a protein:energy ratio of $20.5-21 \mathrm{mg} \cdot \mathrm{kJ}^{-1}$ can represent a critical value not only for sea bass but also for sea bream. According to this, in sea bream, a reliable protein sparing effect in fish fed the $17 \%$ lipid diet is achicved under restricted feeding conditions, but such a beneficial effect might disappear in fish fed to visual satiety. In fact, in this latter case, sea bream fingerlings might be considered to have reached a state of metabolic fasting (increased energy expenditure, although not directly measured here), which would protect adipose tissue, and perhaps other organs and tissues, from excessive lipid deposition when non protein energy substrates are available at too high a level.

Comparisons of plasma GH levels between fish species are difficult due to differences in GH batches and GH-antibody affinity. However, it seems that plasma $\mathrm{GH}$ concentrations in sea bream are of the same order of magnitude as those found in turbot (Psetta maxima) (Le Bail, pers. comm.), and two- to four-fold higher than those of Japanese eel (Anguilla japonica) [12], tilapia (Oreochromis niloticus) [30], rainbow trout (Oncorhynchus mykiss) [29, 36], Atlantic salmon (Salmo salar) [4] and chinook salmon (Oncorhynchus tschwawitscha) [18]. Although the physiological significance of such differences remains to be established, taking into account the key metabolic role of $\mathrm{GH}$, it has been postulated that this fact reflects inter-specific differences in nutrient utilisation and endocrine regulation [27]. It is also worth noting that while a strong positive relationship between growth rates and $T_{3}$ has been reported in rainbow trout [15], Atlantic salmon (Salmo salar) [5, 22] and red drum (Sciaenops ocella$t u s$ ) [23], sparid fish appear to show some refractoriness to changes in circulating levels of thyroid hormones ([9]; Le Bail, pers. comm.). In the present study, plasma GH levels were found to be lower in common dentex than in sea bream. The use of a sea bream GH assay to measure plasma GH levels in common dentex might be considered to have led to some underestimation of $\mathrm{GH}$ values. Nevertheless, given the high GH sequence identity between sea bream [19], Acanthopagrus butcheri [17] and Acanthopagrus latus [39], a low number of amino acid substitutions is expected in another sparid fish, such as common dentex.

One important feature is that sea bream fed with the $17 \%$ lipid diet exhibited higher plasma GH levels than fish fed with the $9 \%$ lipid diet. In earlier studies [21, 28], we have observed that sea bream fed high energy diets at high feeding levels show a persistent hypersomatotropism associated with a diminished feed efficiency. However, this tendency is opposite when energy supply for growth purposes is limiting, as under restricted feeding conditions [6]. According to this, low plasma $\mathrm{GH}$ levels (increased liver GH-responsiveness) in fast growing fish are indicative of an adequate energy balance (energy input/energy expenditure). Data from the fore-mentioned studies also suggest a close negative relation between circulating $\mathrm{GH}$ levels and protein growth expressed as daily $\mathrm{N}$ gain. We also find a very similar pattern in the present study. The absence of an up-regulation of plasma GH levels in common dentex fed the diet with the highest energy content $(17 \%$ lipid diet) is in agrcement with an efficient utilisation of dietary lipids. The low plasma glucose levels in this species provide additional evidence of a true state of low lipogenic potentiality [34]. Whether a further decrease in dietary protein:energy ratio would increase adiposity in growing common dentex warrants investigation.

\section{CONCLUSION}

In comparison with sea bass and sea bream, common dentex not only exhibits high growth rates and protein deposition, but also an increased tolerance to relatively high dietary lipid levels. Plasma growth hormone levels were lower in dentex than in sea bream, indicating the higher growth potential of this species. Given their voracious feeding behaviour, growth potential and protein retention, dentex remains a good candidate for aquaculture. But, although mortality remained low $(4-7 \%)$ in the present study, dentex is known to be highly susceptible to handling and opportunistic pathogens [10].

\section{Acknowledgements}

This work was supported by research grants from 'Generalitat Valenciana' (JACUMAR) and the Spanish 'Ministerio of Educación y Cultura' (PETRI 95-0183-OP). JAC-G was a recipient of a research grant from 'Generalitat Valenciana'.

\section{REFERENCES}

[1] Abellán E., García-Alcázar A., Arizcun M., Delgado J., Martín P., Experiencias preliminares sobre reproducción y cultivo de dentón, (Dentex dentex L.), in: De Costa J., Abellán E., García G.B., Ortega R.A.,
Zamora N.S. (Eds.), Actas del VI Congreso Nacional de Acuicultura, Cartagena, Spain, 9-11 July 1997, pp. 471-476 (in Spanish).

[2] Ballestrazzi R., Lanari D., D'Agaro E., Mion A., The effect of dietary protein levels and source on growth, hody composition, total ammonia and reactive phos- 
phate excretion of growing sea bass (Dicentrarchus labrax), Aquaculture 127 (1994) 197-206.

[3] Ballestrazzi R., Lanari D., D’Agaro E., Performance, nutrient retention efficiency, total ammonia and reactive phosphorus excretion of growing European sea-bass (Dicentrarchus labrax L.) as affected by diet processing and feeding level, Aquaculture 161 (1998) 55-65.

[4] Björsson B.T., Taranger G.L., Hansen T., Stefansson S.O., Haux C., The interrelation between photoperiod, growth hormone, and sexual maturation of adult Atlantic salmon (Salmo salar), Gen. Comp. Endocrinol. 93 (1994) 70-81.

[5] Boeuf G., Gaignon J.J., Effects of rearing conditions on growth and thyroid hormones during smolting of Atlantic salmon Salmo salar, Aquaculture 82 (1989) 29-38.

[6] Calduch-Giner J.A., Company R., Kaushik S., PérezSánchez J., Risk and benefits of lipid enriched diets in gilthead sea bream (Sparus aurata), in: VIII Int. Symp. Nutrition and Feeding of Fish, Las Palmas de Gran Canaria, Spain, 1-4 June 1998, p. 32.

[7] Cardenete G., Abellán E., Hidalgo M.C., Skalli A., Arizcun M., Relación proteína energía en dietas para juveniles de dentón (Dentex dentex), in: De Costa J., Abellán E., García G.B., Ortega R.A., Zamora N.S. (Eds.), Actas del VI Congreso Nacional de Acuicultura, Cartagena, Spain, 9-11 July 1997, pp. 581-585 (in Spanish).

[8] Cardenete G., Skalli A., Hidalgo M.C., Palma M.C., Massuti S., Variaciones en los niveles proteico y lipídico de la dieta. Efecto sobre el crecimiento y utilización nutritiva de la misma por el dentón (Dentex dentex), in: De Cosla J., Abellán E., García G.B., Ortega R.A., Zamora N.S. (Eds.), Actas del VI Congreso Nacional de Acuicultura, Cartagena, Spain, 9-11 July, 1997, pp. 559-564 (in Spanish).

[9] Cerdá-Reverte J.M., Zanuy S., Carrillo M., Kah O., Development of enzyme immunoassay for 3,5,3'-triiodo-L-thyronine and L-thyroxine: time-course studies on the effect of food deprivation on plasma thyroid hormones in two marine teleosts, sea bass (Dicentrarchus labrax L.) and sea bream (Sparus aurata L.), Gen. Comp. Endocrinol. 103 (1996) 290-300.

[10] Company R., Sitjà-Bobadilla A., Pujalte Mª.J., Garay E., Alvarez-Pellitero P., Pérez-Sánchez J., Bacterial and parasitic pathogens in cultured common dentex (Dentex dentex L.), J. Fish Dis. (1998) (in press).

[11] Dias J., Alvarez M.J., Diez A., Arzel J., Corraze G., Bautista J.M., Kaushik S.J., Regulation of hepatic lipogenesis by dielary protein/energy in juvenile European sea bass (Dicentrarchus labrax), Aquaculture 161 (1998) 169-186.

[12] Duan C., Hirano T., Plasma kinetics of growth hormone in the Japanese eel, Anguilla japonica, Aquaculture 95 (1990) $179-188$.

[13] Efthimiou S., Divanach P., Rosenthal H., Growth, food conversion and agonistic behaviour in common dentex (Dentex dentex) juveniles fed on pelleted moist and dry diets, Aquat. Living Resour. 7 (1994) 267-275.

[14] Folch J., Lees M., Stanley S., A simple method for the isolation and purification of total lipids from animal tissues, J. Biol. Chem. 226 (1957) 497-509.

[15] Gomez J.M., Boujard T., Boeuf G., Solari A., Le Bail P.-Y., Individual nycthemeral plasma profiles of thyroid

Aquat. Living Resour. 12 (1) (1999) hormones in rainbow trout (Oncorhynchus mykiss) in relation with cortisol, growth hormone and growth rate, Gen. Comp. Endocrinol. 107 (1997) 74-83.

[16] Hidalgo F., Alliot E., Influence of water temperature on protein requirement and protein utilization in juvenile sea bass, Dicentrarchus labrax, Aquaculture 72 (1988) $115-129$.

[17] Knibb W., Robins A., Crocker L., Rizzon J., Heyward A., Wells J., Molecular cloning and sequencing of Australian black bream Acanthopagrus butcheri and barramundi Lates calcarifer fish growth hormone cDNA using polymerase chain reaction, DNA Sequence 2 (1991) $121-123$.

[18] Le Bail P.-Y., Sumpter J.P., Carragher J.F., Mourot B., Niu P.D., Weil C., Development and validation of a highly sensitive radioimmunoassay for chinook salmon (Oncorhynchus tshawytscha) growth hormone, Gen. Comp. Endocrinol. 81 (1991) 73-85.

[19] Martínez-Barberá J.P., Pendón C., Rodríguez R.B., Pérez-Sánchez J., Valdivia M.M., Cloning, expression, and characterization of a recombinant gilthead sea bream growth hormone, Gen. Comp. Endocrinol. 86 (1994) 179-188.

[20] Martínez-Barberá J.P., Pendón C., Martí-Palanca $H$., Calduch-Giner J.A., Rodriguez R.B., Valdivia M.M., Pérez-Sánchez J., The use of recombinant gilthead sea bream (Sparus aurata) growth hormone for radioiodination and standard preparation in radioimmunoassay, Comp. Biochem. Physiol. 1 10A (1995) 335-340.

[21] Martí-Palanca H., Martínez-Barberá J.P., Pendón C., Valdivia M.M., Pérez-Sánchez J., Kaushik S., Growth hormone as a function of age and dietary protein:energy ratio in a marine teleost, the gilthead sea bream (Sparus aurala), Grow (h Regul. 6 (1996) 253-259.

[22] McCormick S.D., Saunders R.L., Influence of ration level and salinity on circulating thyroid hormones in juvenile Atlantic salmon (Salmo salar), Gen. Comp. Endocrinol. 78 (1990) 224-230.

[23] McKenzie D.S., Moon H.Y., Gatlin D.M., Pérez L.R., Dietary effects of thyroid hormones in the red drum Sciaenops ocellatus, Fish Physiol. Biochem, 11 (1993) 329-335.

[24] Metailler R., Aldrin J.F., Messager J.L., Mevel G., Stephan G., Feeding of European sea bass Dicentrarchus labrax: role of protein level and energy source, J. World Maric. Soc. 12 (1981) 117-118.

[25] Morales-Nin B., Moranta J., Life history and fishery of common dentcx (Dentex dentex) in Mallorca (Balearic Islands, western Mediterranean), Fish. Res. 30 (1997) 67-76.

[26] Pérez L., Gonzalez H., Jover M., Fernández-Carmona J., Growth of European sea bass fingerlings (Dicentrarchus labrax) fed extruded diets containing varying levels of protein, lipid and carbohydrate, Aquaculture 156 (1997) 183-193.

[27] Pérez-Sánchez J., Le Bail P.-Y., Growth hormone axis as a marker of nutritional status and growth performance in fish, Aquaculture (1998) (in press).

[28] Pérez-Sánchez J., Martí-Palanca H., Kaushik S.J., Ration size and protein intake affect growth hormone concentration, hepatic growth hormone binding and plasma insulin-like growth factor I immunoreactivity in 
a marine teleost, the gilthead sea bream (Sparus aurata), J. Nutr. 125 (1995) 546-552.

[29] Pickering A.D., Pottinger T.G., Sumpler J.P., Carragher J.F., Le Bail P.-Y., Effects of acute and chronic stress on the levels of circulating growth hormone in the rainbow trout, Oncorhynchus mykiss, Gen. Comp. Endocrinol. 83 (1991) 86-93.

[30] Ricordel M.J., Smal J., Le Bail P.-Y., Application of a recombinant cichlid growth hormone radioimmunoassay to measure native GH in tilapia (Oreochromis niloticus) bred at different temperatures, Aquat. Living Resour. 8 (1995) 153-160.

[31] Riera F., Pastor E., Grau A.M., Pou S., Grau A., Massuti E., Experiencias en el cultivo del dentón, Dentex dentex (L.), in: Cerviño A., Lardín $\Lambda$., De Coo $\Lambda$., Guerra $\Lambda$., Torre M. (Eds.), Actas del IV Congreso Nacional de Acuicultura, Illa de Arousa, Galicia, Spain, 21-24 September 1993, pp. 143-148 (in Spanish).

[32] Rigos G., Grigorakis K., Nengas I., Christophilogiannis P., Yiagnisi M., Koutsodimou M., Andriopoulou A., Alexis M., Stress related pathology seems a significant obstacle for the intensive farming of common dentex, Dentex dentex (Linnaeus, 1758), Bull. Eur. Ass. Fish Pathol. 18 (1998) 15-18.

[33] Russell N.R., Fish J.D., Wootton R.J., Feeding and growth of juvenile sea bass: the effect of ration and temperature on growth rate and efficiency, J. Fish Biol. 49 (1996) 206-220.

[34] Sidossis L.S., Wolfe R.R., Glucose and insulin-induced inhibition of fatty acid oxidation. The glucose-fatty acid cycle reversed, Am. J. Physiol. 270 (1996) 733-738.
[35] Soljan T., Ribe Jadrama (Pisces, Maris Adriatici), III izdanje, Zavod za izdavanje udzb, SRS, Beograd, 1965, pp. 451.

[36] Sumpter J.P., Le Bail P.-Y., Pickering A.D., Pottinger T.G., Carragher J.F., The effect of starvation on growth plasma growth hormone concentrations of rainbow trout, Oncorhynchus mykiss, Gen. Comp. Endocrinol. 83 (1991) 94-102.

[37] Tandler A., Berg B.A., Kissil G.W., McKie A.M., Effect of food attractants on appetite and growth rate of gilthead sea bream, Sparus aurata L., J. Fish Biol. 20 (1982) 673-681.

[38] Tibaldi E., Beraldo P., Volpelli L.A., Pinosa M., Growth response of juvenile dentex (Dentex dentex L.) to varying protein level and protein to lipid ratio in practical diets, Aquaculture 139 (1996) 91-99.

[39] Tsai H.J., Lin K.L., Chen T.T., Molecular cloning and expression of yellowfin porgy (Acanthopagrus latus Houttuyn) growth hormone cDNA, Comp. Biochem. Physiol. 104B (1993) 803-810.

[40] Tsevis N., Klaoudatos S., Conides A., Food conversion budget in sea bass, Dicentrarchus labrax, fingerlings under two different feeding frequency patterns. Aquaculture 101 (1992) 293-304.

[41] Tulli F., Tibaldi E., Changes in amino acids and essential fatty acids during early larval rearing of dentex, Aquac. Int. 5 (1997) 229-236.

[42] Vergara J.M., Robaina L., Izquierdo M., De La Higera M., Protein sparing effect of lipids in diets for fingerlings of gilthead sea bream, Fish. Sci. 62 (1996) 624 628. 